\title{
The Involvement of Cdk5 Activator p35 in Social Isolation-Triggered Onset of Early Alzheimer's Disease-Related Cognitive Deficit in the Transgenic Mice
}

\author{
Ya-Hsin Hsiao', Po See Chen', Shun-Hua Chen' and Po-Wu Gean*,' \\ I'Institute of Basic Medical Sciences and Department of Pharmacology, Center for Gene Regulation and Signal Transduction Research, National \\ Cheng-Kung University, Tainan, Taiwan
}

\begin{abstract}
Epidemiological studies indicate that isolated persons have increased risk of developing Alzheimer's disease (AD). This study investigated the cellular mechanisms of how social isolation influenced amyloid $\beta$ peptide $(A \beta)$ accumulation and affected the severity of AD-associated cognitive decline in a mouse model of AD. Amyloid precursor protein (APP) and presenilin I (PSI) double-transgenic (APP/PSI) mice were placed either in isolation or in group from postnatal day 28 and tested for cognitive performance at the age of 3 months with fear-conditioning paradigms. We found that social isolation accelerated impairment of contextual fear memory in the APP/PSI mice. The magnitude of long-term potentiation in the hippocampal CAI neurons was significantly lower in the isolated APP/PS I mice compared with group APP/PSI and wild-type mice. Hippocampal level of A $\beta$ was significantly elevated in the isolated APP/PSI mice, which was accompanied by an increased calpain activity and p25/p35 ratio. In addition, surface expression of GluRI subunit of AMPA receptor was decreased by social isolation. The association of $\mathrm{p} 35$, and $\alpha$-CaMKII was significantly less in the isolated APP/PS I mice indicating that their interaction was impaired. These results suggest that social isolation exacerbates memory deficit by increasing $A \beta$ level, leading to the increased calpain activity, conversion of p35 to p25 and decrease in association of p35, $\alpha$-CaMKII, and GluRI, resulting in the endocytosis of AMPA receptors.

Neuropsychopharmacology (20II) 36, I848-1858; doi:I0.1038/npp.20II.69; published online 4 May 20II
\end{abstract}

Keywords: social isolation; amyloid- $\beta$ peptide; long-term potentiation; learning and memory; Alzheimer's disease

\section{INTRODUCTION}

Alzheimer's disease $(\mathrm{AD})$ is the most common form of dementia in older persons that seriously affects a person's memory, thinking, and reasoning skills. In order to prevent or retard the development of syndrome, scientists are finding factors that increase the risk of $\mathrm{AD}$. Recent evidence suggests that the beginning of memory deficits in the developing $\mathrm{AD}$ patients correlates well with $\beta$-amyloid $(\mathrm{A} \beta)$ levels (Lue et al, 1999; McLean et al, 1999). A $\beta$ is derived by proteolysis of an integral membrane protein known as the amyloid precursor protein (APP) (Kang et al, 1987). APP can be cleaved by $\beta$ - and $\gamma$-secretases at the $\mathrm{N}$ and $\mathrm{C}$ termini of $\mathrm{A} \beta$ and releasing $\mathrm{A} \beta$ into the extracellular space (Haass et al, 1992; Shoji et al, 1992). The precise mechanisms by which $\mathrm{A} \beta$ induce memory deficit are still not clear.

*Correspondence: Dr P-W Gean, Department of Pharmacology, College of Medicine, No.I University Road, National Cheng-Kung University, Tainan 70I, Taiwan, Tel: + 88662353535 ext. 5507,

Fax: + 8866 2749296, E-mail: powu@mail.ncku.edu.tw

Received 31 December 2010; revised I4 March 201।; accepted 28 March 201।
Proposed mechanisms include synaptic removal of NMDA receptors (Snyder et al, 2005; Dewachter et al, 2009) and AMPA receptors (Hsieh et al, 2006), disruption of cytoskeletal network and loss of dendritic spines (Knobloch and Mansuy, 2008), activation of protein phosphatase 1 (Knobloch et al, 2007), striatal-enriched tyrosine phosphatase (Zhang et al, 2010) or calcineurin (Zhao et al, 2010), and disruption of neuronal glutamate uptake ( $\mathrm{Li}$ et al, 2009).

Early studies have shown that housing conditions can affect one's behavior and physiology. A study analyzing the association between social isolation and $\mathrm{AD}$ showed that the risk of developing $\mathrm{AD}$ was more than doubled in isolated person. Social isolation was associated with lower level of cognition at baseline and with more rapid decline during follow-up (Wilson et al, 2007). However, social isolation was not related to any change of the brain hallmarks associated with $\mathrm{AD}$ suggesting that social isolation may contribute to risk of $\mathrm{AD}$ and does so through some mechanisms other than $\mathrm{AD}$ pathology.

Cyclin-dependent kinase 5 (Cdk5) is a proline-directed Ser/Thr kinase that is involved in the migration of neurons and the neurite outgrowth during development (Nikolic 
et al, 1996). Cdk5 activity requires association with the activator p35 (Tsai et al, 1994). Neurotoxic stress induces calcium influx and calpain-directed proteolysis of p35 resulting in the release of p25 from an N-terminal membrane tether. p35 has a short cellular half-life and its degradation leads to aberrant activation of p25/Cdk5, which induces tau phosphorylation and contributes directly to the pathogenesis of $\mathrm{AD}$ (Patrick et al, 1999; Noble et al, $2003)$. In a mouse model of $\mathrm{AD}$, prolonged expression of p25 induced by an inducible transgenic system or by lipopolysaccharide resulted in hyperphosphorylation of tau and severe neurodegeneration (Cruz et al, 2003; Fischer et al, 2005; Kitazawa et al, 2005). The purpose of this study was to elucidate the mechanism of how social isolation accelerated the decline of memory in the APP/PS1 mice. APP/PS1 mouse is a double transgenic mouse that overexpress APP together with presenilin 1 (PS1). These mice have an accelerated course of $\mathrm{AD}$-like changes and currently are used by several laboratories for studies on the mechanisms of $\mathrm{AD}$ progression and for the development of new therapeutics (Trinchese et al, 2004). We demonstrated that social isolation rearing increases hippocampal $\mathrm{A} \beta$ levels by increasing $\beta$ - and $\gamma$-secretase activities, resulting in the conversion of p35 to p25. The decrease in membraneassociated p35 reduced the association among p35, $\alpha$-CaMKII, and GluR1, leading to the endocytosis of AMPA receptors.

\section{MATERIALS AND METHODS}

\section{Animals}

APP/PS1 transgenic mice expressing a chimeric mouse/ human APP (Mo/HuAPP695swe) and a mutant human PS1 (PS1dE9) (Jankowsky et al, 2004) were obtained from the Jackson Laboratory (West Grove, PA). The double transgenic (APP/PS1, Tg) mice were backcrossed to C57BL/6J strain for six generations to create APP/PS1 transgenic mice in C57BL/6J background. Wild-type (WT) littermates were used as controls. We used male mice for all experiments. When weaning of postnatal day 28, experimental animals were separated into housed (group; four mice per cage) or individually (isolated; one mice per cage) for a period of about 8 weeks until 3 months of age. Animals were maintained on a 12:12 light-dark cycle in a temperatureand humidity-controlled vivarium and allowed ad libitum access to food and water. All procedures were approved by the Institutional Animal Care and Use Committee of the College of Medicine, National Cheng Kung University.

\section{Fear Conditioning}

Fear conditioning occurred in $30 \times 24 \times 21 \mathrm{~cm}$ operant chamber (Med Associates, St Albons, VT). The chamber was equipped with a shock floor, house light, and speaker mounted on the wall through which tone presentations were delivered. The shock floor consisting of stainless-steel rods was wired to a shock generator for foot shock delivery. The house light provided illumination during all sessions. All were controlled by FreezeScan software (Clever Systems, Reston, VA). The chamber was cleaned with $75 \%$ ethanol before each mouse was trained or tested for contextual fear conditioning. On the first day of training, mice were transported in their home cage to a behavioral room. After a 60-min habituation period in the room, mice were placed in the training chamber for $120 \mathrm{~s}$. After the acclimation period, mice were presented with a pure tone $(20 \mathrm{~s}, 3 \mathrm{kHz})$ that coterminated with foot shock ( $3 \mathrm{~s}, 0.75 \mathrm{~mA})$. This tone-foot shock pairing procedure was repeated four times with an inter-trial interval of $40 \mathrm{~s}$. After the last tone paired shock delivery, mice were allowed to explore the context for $2 \mathrm{~min}$ before removal from the chamber. At $24 \mathrm{~h}$ after training, mice were returned to training chamber $3 \mathrm{~min}$ without exposure to the tone or foot shock for a context fear test. At the end of the contextual test, mice were returned to their home cage. Approximately $1 \mathrm{~h}$ later, mice were placed in a novel context for a $120 \mathrm{~s}$ baseline followed by $3 \mathrm{~min}$ of the tone to assess cue-dependent fear conditioning. The novel context was altered on opaque Plexiglas box. Specifically, grid floors were replaced with smooth Plexiglas floor and the chamber was cleaned with $1 \%$ acetic acid before each mouse was tested. The behavior of mice was recorded by video camera mounted above the conditioning chamber. Freezing was defined as the absence of any movement except for respiration and measured automatically using FreezeScan software. Freezing data are presented as percent time spent freezing.

\section{Electrophysiological Recordings}

Mice brains were rapidly removed and placed in cold oxygenated aCSF solution $(117 \mathrm{mM} \mathrm{NaCl}, 4.7 \mathrm{mM} \mathrm{KCl}$, $2.5 \mathrm{mM} \mathrm{CaCl}, 1.2 \mathrm{mM} \mathrm{MgCl}_{2}, 25 \mathrm{mM} \mathrm{NaHCO}, 1.2 \mathrm{mM}$ $\mathrm{NaH}_{2} \mathrm{PO}_{4}$, and $11 \mathrm{mM}$ glucose). The aCSF was bubbled continuously with $95 \% \mathrm{O}_{2} / 5 \% \mathrm{CO}_{2}$ and had a $\mathrm{pH}$ of 7.4 . Transverse slices of a $400-\mu \mathrm{m}$ thickness were cut by Vibroslice tissue slicer (Camden Instruments, Sileby, UK), and slices were placed in oxygenated aCSF at least $1 \mathrm{~h}$ before recording. Eletrophysiological recording was measured in CA1 region of hippocampus. Electrical stimuli $(150 \mathrm{~s}$ in duration) were delivered at a frequency of $0.05 \mathrm{~Hz}$ and baseline field potentials were adjusted to $40 \%$ of the maximal responses. Long-term potentiation (LTP) was elicited by four trains of tetanic stimulation (TS) $(100 \mathrm{~Hz}$, $1 \mathrm{~s}$ at 1-min interval) at the same stimulation intensity used for baseline.

\section{A $\beta$ ELISA Assay}

The concentration of $\mathrm{A} \beta$ was detected by $\mathrm{A} \beta_{40}$ or $\mathrm{A} \beta_{42}$ Colorimetric ELISA kits (Biosource International, Camarillo, CA) according to the manufacturer's instructions. Hippocampal tissues were extracted by suggested buffers (Johnson-Wood et al, 1997). AEBSF was added to prevent degradation of $\mathrm{A} \beta$ peptides. The absorbance in each well was read with Microplate Reader.

\section{Western Blotting and Immunoprecipitation}

Hippocampal tissues were sonicated by homogenizing buffer ( $1 \%$ Triton X-100, 0.1\% SDS, $50 \mathrm{mM}$ Tris-Hcl, pH $7.5,0.3 \mathrm{M}$ sucrose, $5 \mathrm{mM}$ EDTA, $2 \mathrm{mM}$ sodium pyrophosphate, $1 \mathrm{mM}$ sodium orthovanadate, $1 \mathrm{mM}$ enylmethylsulfonyl fluoride, $20 \mu \mathrm{g} / \mathrm{ml}$ leupeptin, and $4 \mu \mathrm{g} / \mathrm{ml}$ aprotinin). 
Lysates were centrifuged at 12000 r.p.m. for $30 \mathrm{~min}$. Supernatants were collected and then protein concentration was measured using a Bradford assay. For immunoprecipitation assay, the extract lysate $(400 \mu \mathrm{g})$ from the supernatant was precipitated with anti-p35 (N20), anti- $\alpha$-CaMKII, antiGluR1, or anti-PSD95 antibodies $(2 \mu \mathrm{g})$ for overnight at $4{ }^{\circ} \mathrm{C}$ and subsequently incubated with protein $G$ sepharose $\left(40 \mu \mathrm{l}\right.$, Sigma) or rabbit IgG TrueBlot for $1 \mathrm{~h}$ at $4{ }^{\circ} \mathrm{C}$. Rabbit IgG TrueBlot was obtained from eBioscience and used to avoid hindrance by interfering immunoprecipitating immunoglobulin heavy and light chains. The immunoprecipitated pellets were washed four times with homogenizing buffer. Bound proteins were resuspended in $8 \mu \mathrm{l}$ of SDS sample buffer and subjected to electrophoresis on $8.5 \sim 12 \%$ SDS-polyacrylamide gel, and transferred to a nitrocellulose membrane. The blot was incubated in 5\% nonfat dry milk for $60 \mathrm{~min}$, western blot analysis used a p35 (C-19), p35 (N20) (1:5000; Santa Cruz Biotechnology), $\alpha$-CaMKII (1:5000; Abcam), PSD95 (1:1000; Santa Cruz Biotechnology), GluR1 (1:1000; Santa Cruz Biotechnology), PKC $\delta$ (1:5000; BD Biosciences Pharmingen), or tubulin (1:10 000; Sigma) antibody reacted overnight at $4{ }^{\circ} \mathrm{C}$, and then incubated with HRP-conjugated secondary antibodies for $1 \mathrm{~h}$ at room temperature. Immunoreactivity was detected by using the western blot chemiluminescence reagent system (PerkinElmer, Boston, MA). Films were exposed at different times to ensure optimum density but not saturated. To assess for changes in the protein expression levels, they were first normalized to internal control levels for each sample and then were expressed as a percentage of those in WT controls, respectively.

\section{Surface Biotinylation Assay}

Hippocampal slices were incubated with aCSF containing $0.5 \mathrm{mg} / \mathrm{ml}$ Sulfo-NHS-LC-Biotin (Pierce Chemical, Rockford, IL) for $1 \mathrm{~h}$ on ice and were sonicated by homogenizing buffer. Lysates were centrifuged at 12000 r.p.m. for $30 \mathrm{~min}$. Supernatants were collected and protein concentration was then measured using a Bradford assay. Biotinylated protein $(400 \mu \mathrm{g})$ from the supernatant was precipitated with $40 \mu \mathrm{l}$ of $50 \%$ Neutravidin agarose (Pierce Chemical) for $16 \mathrm{~h}$ at $4{ }^{\circ} \mathrm{C}$ and washed four times with homogenizing buffer. Bound protein was resuspended in $8 \mu$ l of SDS sample buffer. Biotinylated protein was subjected to electrophoresis on $8.5 \%$ SDS-polyacrylamide gel, and transferred to a nitrocellulose membrane as western blot assay. Surface GluR1 receptors was detected by a biotinylation assay, followed by western blot analysis that used a GluR1antibody reacted overnight at $4{ }^{\circ} \mathrm{C}$, and then incubated with HRPconjugated secondary antibody for $1 \mathrm{~h}$ at room temperature. Immunoreactivity was detected by using the western blot chemiluminescence reagent system (PerkinElmer).

\section{Calpain Activity}

Calpain activity was measured by using a calpain activity assay kit (Biovision, Mountain View, CA) according to the manufacturer's instructions. Calpain activity was calculated as relative fluorescence intensity that was based on cleavage of calpain substrate Ac-LLY-AFC. This signal was read at an excitation/emission wavelength of 400/505 nm. All samples were run in triplicates.

\section{Surgery}

APP/PS1 mice (25-30 g), anesthetized with sodium pentobarbital $(50 \mathrm{mg} / \mathrm{kg}$, i.p.), were mounted on a stereotaxic apparatus. The cannulas made of 26 gauge stainless-steel tubing were implanted into the dorsal hippocampus (anteroposterior, $-2.3 \mathrm{~mm}$; mediolateral, $\pm 1.8 \mathrm{~mm}$; dorsoventral, $-1.5 \mathrm{~mm}$ ). After 7 days to recover, lentivirus, calpeptin, MG132, or vehicle (DMSO: sterile phosphatebuffered saline $=20: 80$ ) was administered bilaterally to the hippocampus in a volume of $1 \mu \mathrm{l}$ at rate of $0.1 \mu \mathrm{l} / \mathrm{min}$. The infusion cannulas were left $10 \mathrm{~min}$ before withdraw.

\section{shRNA Virus Production}

Lentivirus was generated using plasmid triple-transfection of the lentivirus vector plasmid, packing, and small hairpin interfering RNA (shRNA) plasmid into HEK293T cells. Viral particles were purified and concentrated to yield $1 \times 10^{8}-$ $1 \times 10^{9}$ infectious particles per ml. The p35-shRNA, PKC $\delta$ shRNA, or scramble shRNA conjugated on the vector of pLKO.1 with puromycin-resistant region was provided by National RNAi Core Facility (Institute of Molecular Biology, Academia Sinica, Taiwan). Lentivirus was administered to mice at the age of 10 weeks. Silencing gene expression was reached maximal after 2 weeks injection. The target sequence of p35-shRNA, PKC $\delta$-shRNA, or scramble shRNA is described as follows:

p35-shRNA: 5'-CGCGCATCTAACAATGAGAA-3'

(scramble shRNA: $5^{\prime}$-CCTCAACAATGAGAACCTGAA-3')

PKC $\delta$-shRNA: $5^{\prime}$-CCTCACCGATTCAAGGTTTAT-3'

(scramble shRNA: $5^{\prime}$-GAATCCCAAGTTTGAGCAATT-3')

\section{Statistical Analysis}

All values represent mean \pm SEM. Two-way ANOVA and Newman-Keuls post hoc comparisons were used to analyze the differences in freezing responses and LTP among group, isolated WT, and group, isolated APP/PS1 mice. The level of significance was $p<0.05$.

\section{RESULTS}

\section{Social Isolation Facilitates Impairment of Contextual Fear Memory in App/Ps1 Mice}

When weaning of postnatal day 28, APP/PS1 and WT mice were randomly assigned to group or isolated cages until at the age of 3 months when behavioral tests were performed. We first determined if social isolation might regulate long-term memory formation using cued and contextual fear-conditioning paradigms. The retention of memory was tested $24 \mathrm{~h}$ after training. As shown in Figure 1a, contextual freezing response of the group APP/PS1 mice was comparable to age-matched WT littermates, whereas the magnitude of freezing in the isolated APP/PS1 mice was significantly lower than all other three groups $\left(\mathrm{F}_{(1,56)}=36.66, n=15\right.$ in each group, $p<0.001)$. As a positive control, APP/PS1 mice of 6-month old (housed in group) were tested. These mice 
exhibited impaired memory with freezing responses similar to that of isolated 3-month APP/PS1 mice $\left(t_{(30)}=0.59\right.$, $p>0.5)$. We next assessed memory for cue. We found that there was no significant difference in tone-induced freezing among four different groups $\left(\mathrm{F}_{(3,56)}=0.15, n=15\right.$ in each group, $p>0.1$ ) (Figure $1 \mathrm{~b}$ ) suggesting that APP/PS1 mice
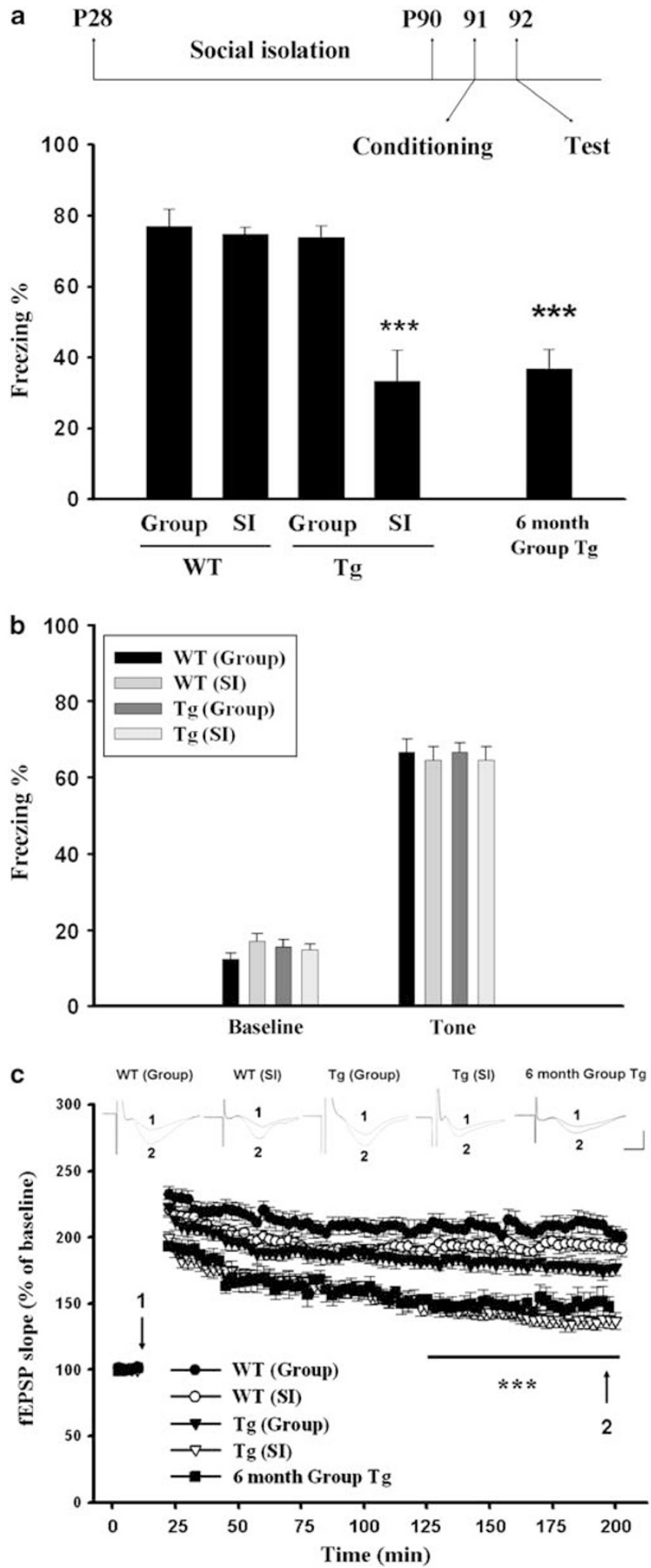

exhibit normal amygdala-dependent fear learning, and that they are able to exhibit normal freezing behavior. These results suggest that APP/PS1 mouse's memory is intact at 3 months old and is impaired at the age of 6 months. Social isolation facilitates impairment of memory in the 3 months old APP/PS1 mice.

It is generally recognized that the hippocampus is mainly involved in contextual fear conditioning (Kim and Fanselow, 1992; Phillips and LeDoux, 1992) whereas simple cue fear conditioning relies on the amygdala and its inputs and outputs (Davis, 2006). Therefore, we investigated LTP in the hippocampal CA1 neurons. One hour after behavioral tests, mice were killed and hippocampal slices were made for electrophysiological recordings. Bipolar stimulating electrode was placed on the Schaffer collaterals and glass recording electrode was positioned in the CA1 stratum radiatum to record field excitatory postsynaptic potentials. Delivery of four sets of TS $(100 \mathrm{~Hz}$ for $1 \mathrm{~s})$ at an inter-stimulus interval of $1 \mathrm{~min}$ to the Schaffer collaterals produced a robust enhancement of synaptic responses (LTP) in the CA1 neurons that persisted for $>3 \mathrm{~h}$. A two-way ANOVA revealed a main effect of genotype (WT $v s$ APP/PS1 mice, $\mathrm{F}_{(1,25)}=49.95$, $p<0.001$ ), housing condition (group $v s$ isolation, $\mathrm{F}_{(1,25)}=$ $22.26, p<0.001$ ), and a tendency toward a significant genotype by housing condition interaction $\left(\mathrm{F}_{(1,25)}=4.12, p=0.0531\right)$. Post hoc analyses showed that group APP/PS1 mice exhibited levels of LTP (measured at $180 \mathrm{~min}$ after HFS) lower than agematched WT littermates $(p<0.01)$. In addition, the magnitude of LTP in the isolated APP/PS1 mice was significantly lower than group APP/PS1 mice $(p<0.001)$ suggesting the impairment of LTP after social isolation in the APP/PS1 mice. As a positive control, APP/PS1 mice of 6-month old (housed in group, $n=4$ ) were tested. These mice exhibited impaired LTP with magnitude of LTP similar to that of isolated 3-month APP/PS1 mice $\left(t_{(10)}=1.62, p>0.1\right)$ (Figure 1c).

\section{Social Isolation Increases Hippocampal Levels of $A \beta_{40}$ and $\mathrm{A} \boldsymbol{\beta}_{42}$}

Group and isolated mice were killed at the age of 3 months, hippocampi were dissected, and levels of $\mathrm{A} \beta_{42}$ and $\mathrm{A} \beta_{40}$ were determined by sandwich ELISA. No difference in $\mathrm{A} \beta_{42}$

Figure I Acceleration of memory impairment and LTP rundown by social isolation in the 3-month-old APP/PSI mice. (a) APP/PSI mice and WT littermate controls were randomly assigned to group or social isolated (SI) groups at postnatal day 28. On postnatal day 9I, the mice received four tone-shock pairings and $24 \mathrm{~h}$ later freezing responses was measured as an index for memory retention. Freezing response was significantly lower in the isolated APP/PSI mice compared with other groups $(n=15$ in each group, **** $p<0.001$ ). For a control experiment, APP/PSI mice of 6 -month old (housed in group) were tested. These mice $(n=16)$ exhibited impaired memory with freezing responses similar to that of isolated 3-month-old APP/PSI mice. (b) At $24 \mathrm{~h}$ after training, mice were placed back into the novel context with altered visual, tactile, and odor cues and tested for amygdala-dependent fear learning ( $n=15$ in each group). (c) Hippocampal slices were made from 3-month-old WT and APP/PSI mice. Delivery of four sets of TS $(100 \mathrm{~Hz}$ for I s) at an inter-stimulus interval of I min to the Schaffer collaterals produced a robust LTP. However, in isolated APP/PSI mice, LTP declined faster than other groups $(n=6$ mice in each group, I-2 slices per mouse, $* * * * 2<0.00 \mathrm{I}$ ). As a positive control, APP/PSI mice of 6-month old (housed in group, $n=4$ ) were tested. These mice exhibited impaired LTP with magnitude of LTP similar to that of isolated 3-month APP/PSI mice $\left(t_{(10)}=1.62, p>0.1\right)$. Calibration: I mV, $10 \mathrm{~ms}$. 

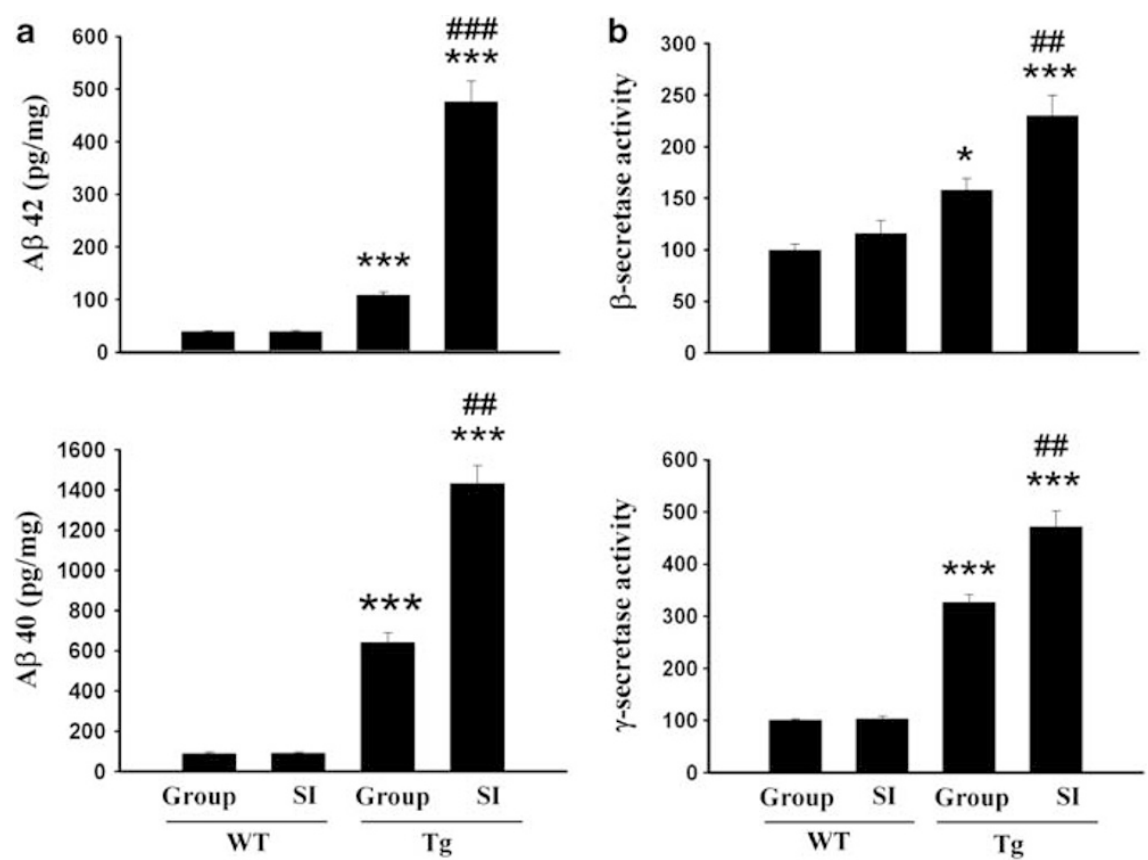

Figure 2 Social isolation increases hippocampal levels of $A \beta_{40}$ and $A \beta_{42}$ in the APP/PSI mice. (a) Group and isolated mice were killed at the age of 3 months, hippocampi were dissected, and levels of $A \beta_{42}$ (upper column) and $A \beta_{40}$ (lower column) were determined by sandwich ELISA (n=6 in each group). APP/PSI mice exhibited significantly higher levels of $A \beta_{40}$ and $A \beta_{42}$ compared with those of WT mice. Moreover, the levels of $A \beta_{40}$ and $A \beta_{42}$ were significantly higher in the isolated APP/PSI mice than in the group APP/PSI mice. ${ }^{* * * *} p<0.00$ I vs WT mice. \#\#\# $p<0.00$ I, \#\#p<0.0 I vs group Tg mice. (b) APP/PSI mice exhibited significantly higher levels of $\beta$ - and $\gamma$-secretase activities compared with those of WT mice $(n=6$ in each group). Moreover, $\beta$ - and $\gamma$-secretase activities were significantly higher in isolated APP/PSI mice than in group APP/PSI mice. ${ }^{*} p<0.05, * * * p<0.001$ vs WT mice. ${ }^{\# \# \#} p<0.00$ I, \#\# $<0.01$ vs group Tg mice.

and $\mathrm{A} \beta_{40}$ (Figure 2a) levels was seen between group and isolated WT mice $(p>0.5)$. However, APP/PS1 mice exhibited significantly higher levels of $\mathrm{A} \beta_{40}$ and $\mathrm{A} \beta_{42}$ compared with age-matched WT mice $(p<0.001)$. Moreover, the levels of $\mathrm{A} \beta_{40}(p<0.01)$ and $\mathrm{A} \beta_{42}(p<0.001)$ were significantly higher in the isolated APP/PS1 mice than in the group APP/ PS1 mice.

$\mathrm{A} \beta$ is derived from $\beta$-APP by sequential proteolytic cleavages from $\beta$-secretase (BACE1) and PS $1 / \gamma$-secretase (Koo and Squazzo, 1994; Perez et al, 1999). We investigated whether isolation-induced increase in $\mathrm{A} \beta$ was due to an increased enzyme activity responsible for $\mathrm{A} \beta$ production. Figure $2 \mathrm{~b}$ shows that APP/PS1 mice exhibited significantly higher levels of $\beta$ - and $\gamma$-secretase activities than their agematched WT mice. In addition, the levels of $\beta$ - $(p<0.01)$ and $\gamma$-secretase $(p<0.01)$ activities were significantly higher in the isolated APP/PS1 mice than in the group APP/PS1 mice. In contrast, $\alpha$-secretase was not appreciably affected (data not shown).

Insulin-degrading enzyme (IDE) and neprilysin (NEP) are brain peptidases involved in the catabolism of $\mathrm{A} \beta$ (Iwata et al, 2001; Farris et al, 2003). Overexpression of NEP or IDE in neurons of transgenic mice showed reduction in the levels of soluble $\mathrm{A} \beta$, prevention of amyloid plaque formation, and extension of lifespan (Leissring et al, 2003). We determined whether social isolation affected NEP and IDE by immunoblotting the expression of IDE and NEP with anti-IDE and anti-NEP antibodies in the APP/PS1 mice. As illustrated in Supplementary Figure 1, neither IDE nor NEP was affected by social isolation.

\section{Social Isolation Enhances the Conversion of p35 to p25}

In cultured neurons, we have previously shown that $\mathrm{A} \beta_{25-35}$ induced cell death by causing a significant decrease in the level of p35 with a concomitant increase in p25 (Hsiao et al, 2008). We examined the possibility that social isolation exacerbates cognitive impairment in the APP/PS1 mice by regulation of $\mathrm{p} 35$ turnover. Whole cell lysates were prepared from WT and APP/PS1 mice, and were blotted with antibody against C-terminal of p35. As shown in Figure 3a, p25/p35 ratio was significantly higher in the APP/PS1 mice than in the WT mice $(p<0.01)$. Moreover, $\mathrm{p} 25 / \mathrm{p} 35$ ratio in the isolated APP/PS1 mice was significantly higher than that of group APP/PS1 mice $\left(\mathrm{F}_{(3,20)}=65.47, p<0.001\right)$. Equal loading was confirmed by immunodetection of Cdk5 in the lysates. Next, whole cell lysates were immunoprecipitated with anti-Cdk5 antibody, and Cdk5 kinase activity was measured. As shown in Figure $3 \mathrm{~b}$, Cdk5 activity was significantly higher in the isolated APP/PS1 mice than in the group APP/PS1 mice $\left(\mathrm{F}_{(3,20)}=112.3, p<0.001\right)$. These results suggest that social isolation enhances the conversion of p35 to p25 in the APP/PS1 mice.

Calpain cleaves p35 into an N-terminal p10 fragment and a C-terminal p25 fragment (Patrick et al, 1999; Kusakawa et al, 2000; Lee et al, 2000). If social isolation acts via decreasing p35 level, then it may affect calpain activity. Figure $4 \mathrm{a}$ shows that calpain activity was significantly higher in the APP/PS1 mice than in the WT mice $(p<0.01)$. Social isolation did not affect calpain activity in the WT controls $(p>0.05)$. However, calpain activity in the isolated 

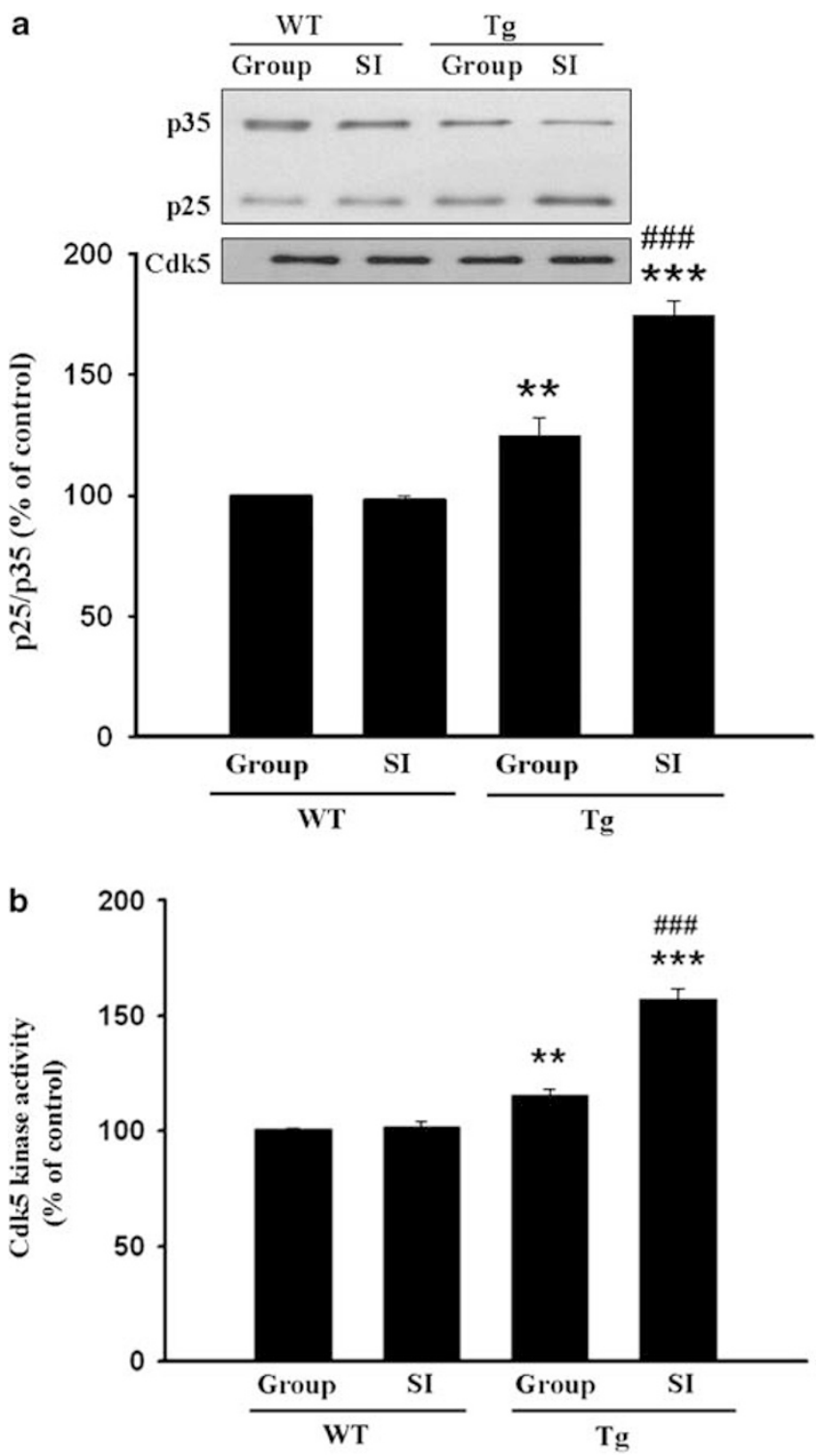

Figure 3 Social isolation enhances the conversion of p35 to p25 in the APP/PSI mice. (a) Whole cell lysates from group and isolated APP/PS I mice were prepared and immunoblotted with antibody against C-terminal of p35. APP/PSI mice exhibited significantly higher ratios of p25/p35 compared with those of WT mice. Moreover, the ratio of p25/p35 was significantly higher in the isolated APP/PSI mice than in the group APP/PS I mice ( $n=6$ in each group). (b) Cell extracts were subjected to immunoprecipitated with anti-Cdk5 antibody and Cdk5 kinase activity was measured by radioactivity ( $n=6$ in each group). $* * * 0.01$, **** $p<0.001$ vs WT mice. ${ }^{\# \# \#} p<0.001$, vs group Tg mice.

APP/PS1 mice was significantly higher than that of the group APP/PS1 mice $(p<0.001)$. To further investigate the role of calpain in the effect of social isolation, we injected calpain inhibitor calpeptin $(10 \mu \mathrm{M}, 1 \mu \mathrm{l}$ per side) or vehicle into the hippocampus for 5 consecutive days. Mice were fear conditioned the following day and freezing responses were assessed $24 \mathrm{~h}$ later. One hour after the behavioral test, mice were killed and membrane-associated p35 (p35-N) were measured using (N20) p35 antibody. As shown in Figures $4 \mathrm{~b}$, social isolation-induced decrease in $\mathrm{p} 35-\mathrm{N}$ was rescued by calpeptin pretreatment. Furthermore, isolationinduced decline of freezing response (Figure 4c) and LTP (Figure 4d) in the APP/PS1 mice was reversed by calpeptin pretreatment.

p35 is subjected to ubiquitin-mediated proteolysis and therefore is short-lived with a half-life $\left(t_{1 / 2}\right)$ of about $30 \mathrm{~min}$. Indeed, proteasome inhibitors such as MG132 greatly stabilize p35 in vivo (Patrick et al, 1998). We determined the effects of proteasome inhibitor MG132 on membrane level of p35. MG132 was bilaterally injected into the hippocampus $(10 \mu \mathrm{M}, 1 \mu \mathrm{l}$ per side) for 5 consecutive days. As illustrated in Figure 4b, social isolation-mediated decrease in p35 was inhibited by MG132. Furthermore, isolationinduced decline of freezing response (Figure 4c) and LTP (Figure 4d) in the APP/PS1 mice was reversed by MG132 pretreatment.

If social isolation facilitates cognition decline via regulation of $\mathrm{p} 35$, then silencing $p 35$ gene expression with shRNA should mimic the effect of social isolation. As depicted in the Figure 5a, after treatment with p35 shRNA, the levels of $\mathrm{p} 35$ in the group APP/PS1 mice were $28.6 \pm 3.6 \%(n=6$ in each group, $p<0.001$ ) of scramble shRNA controls. Importantly, freezing response in the group APP/PS1 mice injected with shRNA $(36.8 \pm 5.8, n=6)$ was much lower than that treated with scramble shRNA $(77.6 \pm 3.8 \%, n=6$, $p<0.001$ ).

It has been shown that PKC $\delta$ stabilizes $\mathrm{p} 35$ by direct phosphorylation and attenuation of p35 degradation (Zhao et al, 2009). Figure 5b shows that the levels of PKC $\delta$ and p35 in the group APP/PS1 mice treated with PKC $\delta$ shRNA were $30.9 \pm 4.4 \%(n=6$ in each group, $p<0.001)$ and $43.3 \pm$ $6.2 \%(n=6$ in each group, $p<0.001)$ of scramble shRNA controls. The freezing response in the group APP/PS1 mice injected with $\mathrm{PKC} \delta$ shRNA $(45.0 \pm 4.8, n=8)$ was much lower than that treated with scramble shRNA $(73.4 \pm 3.7$, $n=8, p<0.001$ ) (Figure 5c).

\section{Social Isolation Decreases Surface Expression of AMPARs}

GluR1 phosphorylation at Ser831 by CaMKII is required for LTP (Barria et al, 1997; Gu et al, 2009) and A $\beta$ decreases AMPAR delivery to synapses by reducing CaMKII synaptic distribution (Mammen et al, 1997). We determined whether GluR1 Ser831 phosphorylation and surface expression of GluR1 subunit of AMPA receptor was affected by social isolation. Figure 6a shows that surface expression of GluR1 and GluR1 Ser831 phosphorylation was significantly less in the hippocampus of isolated APP/PS1 mice compared with those of WT and group APP/PS1 mice. We also used (N20) p35 antibody to detect membrane-associated p35 and the result revealed that level of membrane-associated p35 was significantly decreased in the isolated APP/PS1 mice. Does membrane $\mathrm{p} 35$ level influence surface GluR 1 expression? To address this issue, we plotted membrane p35 vs surface GluR1 in the same animal from group and isolated WT and APP/PS1 mice (six animals in each group). As shown in Figure $6 \mathrm{~b}$, there is a strong correlation between the level of membrane p35 and surface GluR1 $\left(r^{2}=0.83\right)$.

We next investigated the mechanism by which p35 regulated the number of GluR1 at the cell surface. We performed immunoprecipitation from mice hippocampal lysate using 

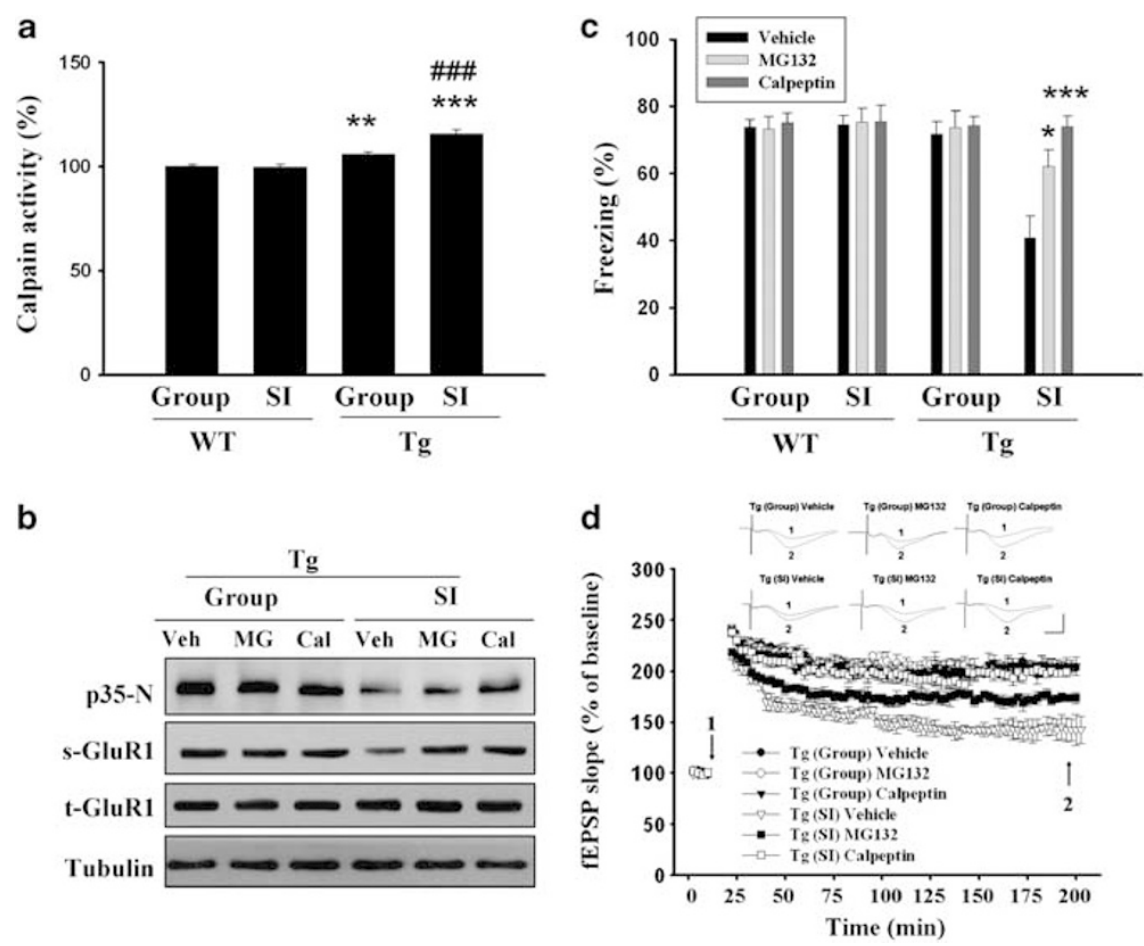

Figure 4 Social isolation increases calpain activity in APP/PSI mice. (a) Whole cell lysates from group and isolated mice were prepared and assayed for calpain activity. Calpain activity was significantly higher in the isolated APP/PSI mice than in the group APP/PSI and WT mice ( $n=6$ in each group). *** $p<0.0$ I, **** $p<0.00$ I vs WT, ${ }^{* \#} p<0.001$ vs group APP/PSI mice. (b) Effects of calpain and proteasome inhibitors on the stability of p35 and surface expression of GluRI. Calpain inhibitor calpeptin ( I $\mu \mathrm{M}$, I $\mu$ l per side), proteasome inhibitor MG I 32 ( I $0 \mu \mathrm{M}$, I $\mu$ l per side) or vehicle was bilaterally injected into the hippocampus for 5 consecutive days. Mice were fear conditioned the following day and freezing responses were assessed $24 \mathrm{~h} \mathrm{later}$. One hour after the behavioral test, mice were killed and membrane-associated p35 (p35-N) and surface GluRI were measured using (N20) p35 antibody. Social isolationinduced decrease in p35-N and surface GluRI in the APP/PSI mice could be rescued by calpeptin or MGI32 ( $n=5$ in each group). (c) Social isolationinduced decrease in the freezing responses could be rescued by calpeptin or MGI32 ( $n=5$ in each group). (d) Social isolation-induced decrease in the magnitude of LTP could be rescued by calpeptin or MGI32 ( $n=4$ mice in each group, $1-2$ slices per mouse).

antibody against p35 to determine whether p35 interacted with $\alpha$-CaMKII, GluR1, and PSD-95. We found that $\alpha$-CaMKII, GluR1, and PSD-95 were detected in p35 immunoprecipitates (Figure 6c). Reciprocal immunoprecipitations using antibodies against $\alpha$-CaMKII, GluR1, and PSD-95 confirmed their association with p35. In addition, the association between $\alpha$-CaMKII and p35 was significantly less in the isolated APP/PS1 mice compared with those of $\mathrm{WT}$ and group APP/PS1 mice $\left(\mathrm{F}_{(3,20)}=66.9, p<0.001\right)$ (Figure 6d) suggesting that interaction was impaired in the isolated APP/PS1 mice. Furthermore, social isolationinduced decrease in surface GluR1 was reversed by MG132 and calpeptin (Figures $4 \mathrm{~b}$ and $\mathrm{c}$ ). These results suggest that social isolation facilitates the conversion of p35 to p25 resulting in decreased surface AMPA receptors and subsequently the impairment of LTP and fear memory.

We then asked whether or not aging process and social isolation-facilitated cognition decline share a similar phenomenon. WT and APP/PS1 mice (housed in group) of 1, 3, 6, and 12 months old were conditioned and $24 \mathrm{~h}$ tested for contextual fear memory. One hour later they were killed for membrane p35 and surface GluR1 measurement. Figure 7a shows that membrane p35 and surface GluR1 were reduced in APP/PS1 mice of 6 and 12 months old. In parallel, fear memory also was impaired in these mice (Figure 7b).

\section{DISCUSSION}

It is known that social isolation is a risk factor for the development of AD. Using APP/PS1 mutant mice at the age of 3 months when their cognitive performance are still normal, we showed that social isolation (1) accelerated the impairment of contextual fear memory and the rundown of hippocampal LTP; (2) enhanced $\beta$ - and $\gamma$-secretase activities and increased hippocampal levels of $\mathrm{A} \beta_{40}$ and $\mathrm{A} \beta_{42}$; (3) increased calpain activity and p25/p35 ratio concomitant with decrease in membrane-associated p35; (4) decreases GluR1 Ser831 phosphorylation and surface expression of AMPARs likely via interfering with the association of $\mathrm{p} 35$, $\alpha$-CaMKII, and GluR1. These results provide an intriguing explanation of how social isolation exacerbates the impairment of cognitive function in the developing AD. Finally, the hypothesis was supported by the observation that membrane p35 and surface GluR1 were reduced in the APP/ PS1 mice of 6 and 12 months old. In parallel, these mice also exhibited impaired contextual fear memory.

\section{Acceleration of Memory Impairment by Social Isolation}

Advancing age, genetic mutations, and environmental factors such as chronic stress are known to increase the likelihood of developing AD. In the training period, freezing 
a
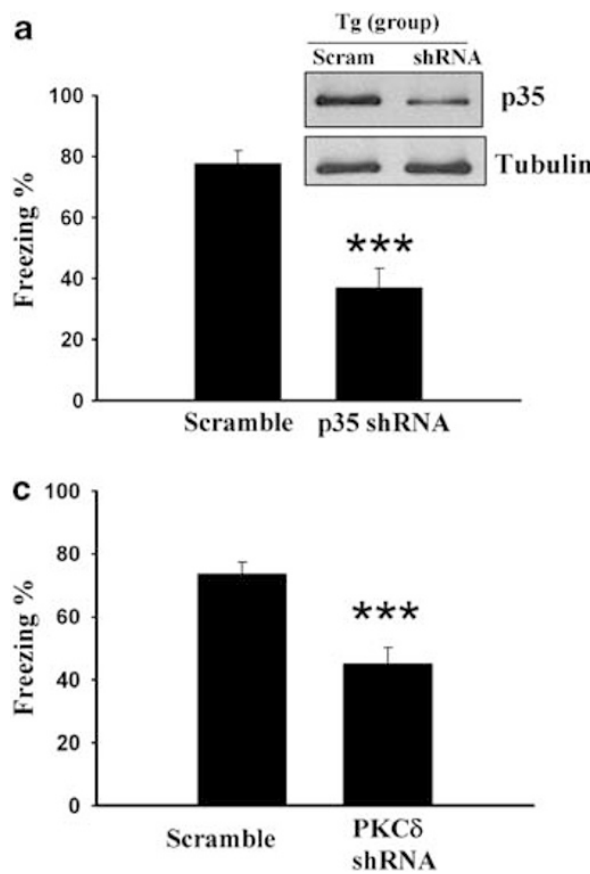

b
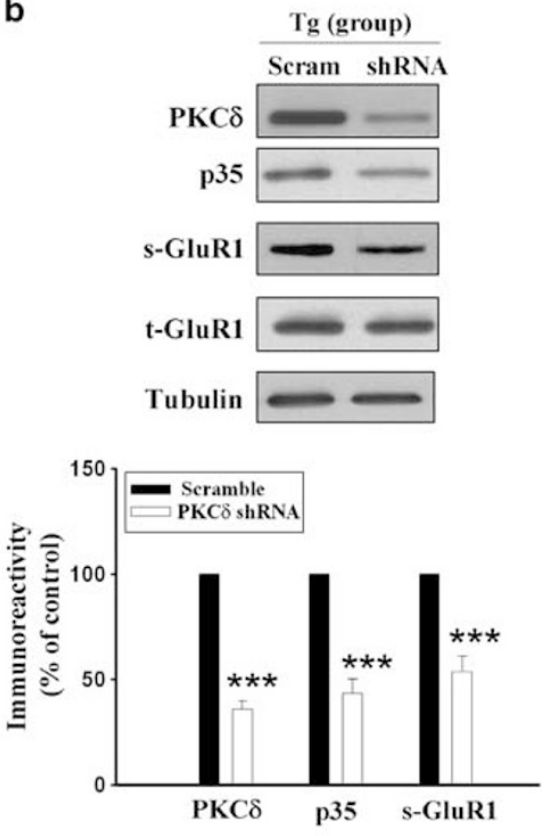

Figure 5 Involvement of p35 in isolation-induced acceleration of cognition decline. p35 shRNA, PKC $\delta$ shRNA or scramble shRNA was injected bilateral into the hippocampus two weeks before the behavioral experiments (at the age of 10 weeks). (a) Western blotting analysis of p35 expression in hippocampal neurons and freezing responses in the group APP/PSI mice transfected with p35 shRNA or scramble shRNA ( $n=6$ in each group). **** $p<0.00$ I vs scramble shRNA. (b) Western blotting analysis of PKC $\delta$, p35 and surface GluRI expression in hippocampal neurons transfected with PKC $\delta$ shRNA or scramble shRNA ( $n=6$ in each group). ${ }^{*} * * *<0.001$ vs scramble shRNA. (c) Freezing responses in the group APP/PSI mice transfected with $\mathrm{PKC} \delta$ shRNA or scramble shRNA ( $n=8$ in each group). ${ }^{*} * * * 0.001$ vs scramble shRNA.

a

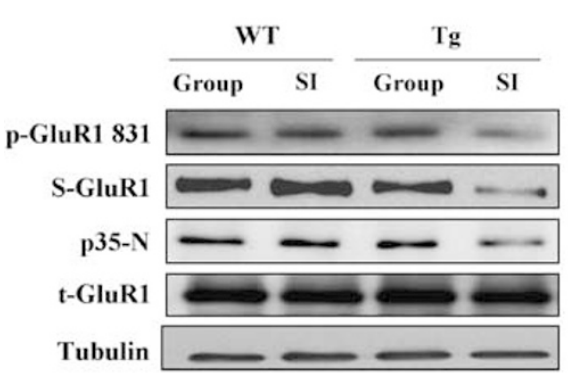

b

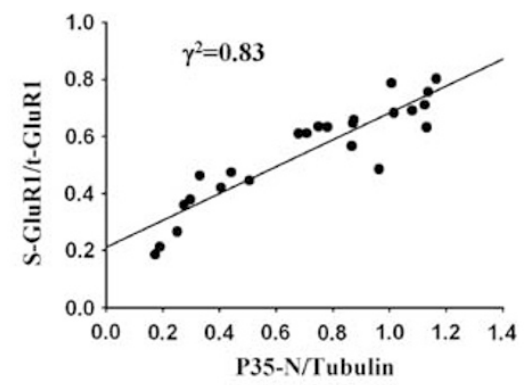

C

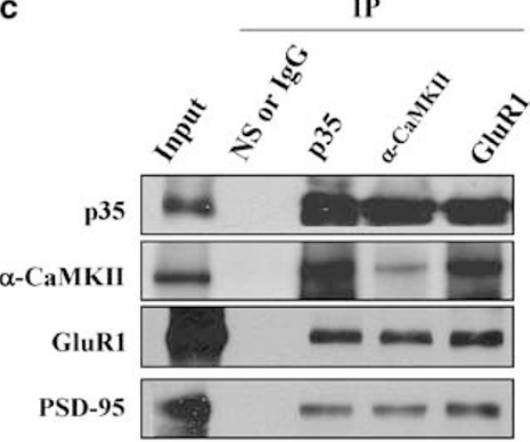

d IP: $\alpha$-CaMKII WT Tg

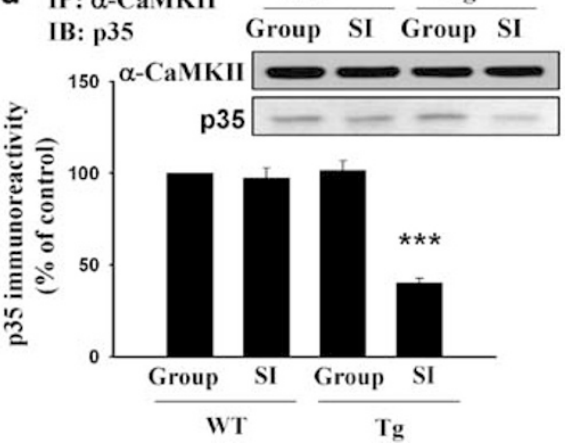

Figure 6 Social isolation decreases phosphorylated levels of GluRI S83I. (a) Group and isolated mice were killed at the age of 3 months, hippocampi were dissected, and GluRI Ser83I phosphorylation, surface GluRI, p35-N, and total GluRI were analyzed by western blot analysis ( $n=6$ in each group). (b) Plotting p35-N vs surface GluRI/total GluRI in the same animal from group and isolated WT and APP/PSI mice (six animals in each group) revealed a linear relationship $\left(r^{2}=0.83\right)$. (c) p35 was physically associated with $\alpha$-CaMKII and GluRI. $\alpha$-CaMKII, GluRI and p35 antibodies were used for immunoprecipitation and the immunoprecipitated samples were resolved by SDS-PAGE. The amount of associated $\alpha$-CaMKII, GluRI, and p35 were analyzed by western blotting $(n=4)$. (d) Social isolation decreases association of p35 and $\alpha$-CaMKIl. $\alpha$-CaMKII antibody was used for immunoprecipitation and the immunoprecipitated samples were resolved by SDS-PAGE. The amount of associated p35 was analyzed by western blotting $(n=6$ in each group). $* * * *<<0.00$ I vs WT. 
a1
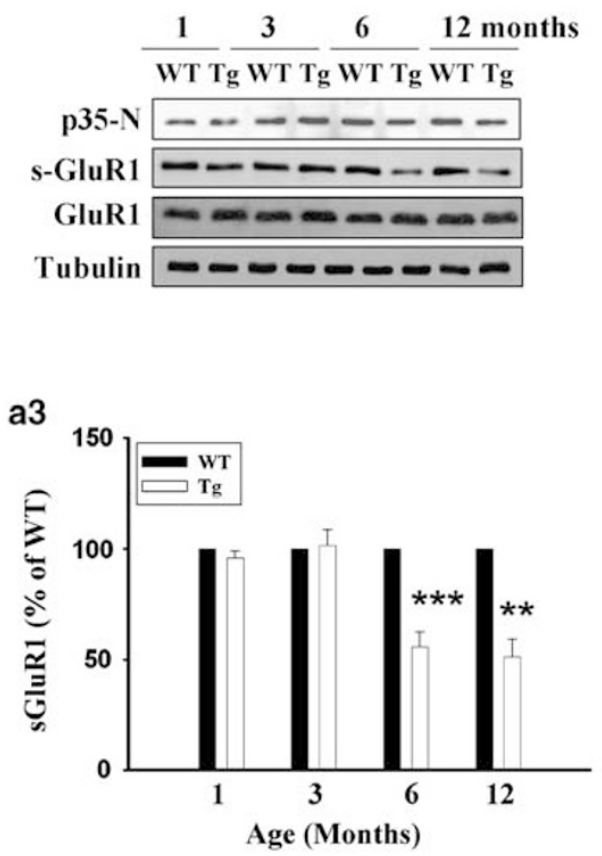

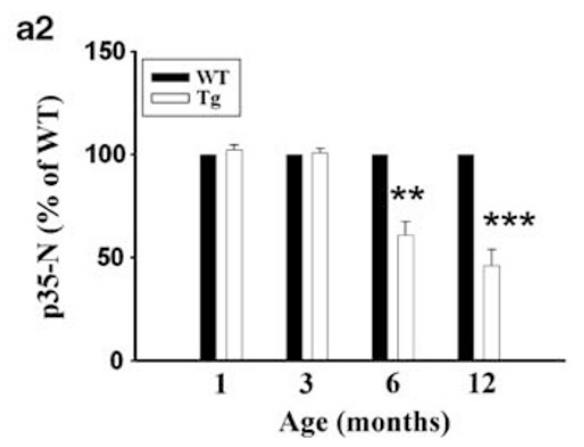

b

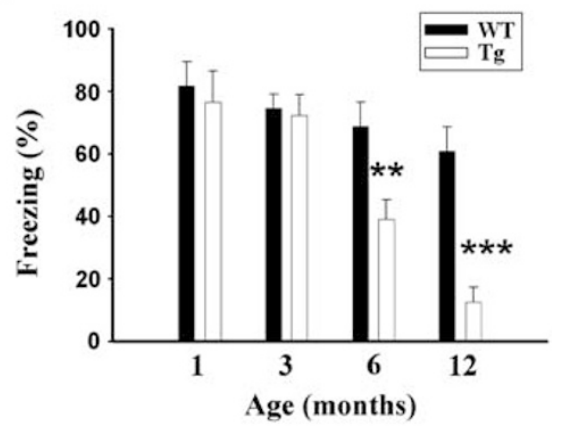

Figure 7 Social isolation-facilitated cognition decline and aging process share similar phenomenon. (al) One hour later they were killed for membrane p35 (a2) and surface GluRI (a3) measurement ( $n=6$ in each group). ${ }^{*} * p<0.0$ I, **** $p<0.00$ I vs age-matched WT littermates. (b) WT and APP/PSI mice (housed in group) of $1,3,6$, and 12 months old were conditioned and $24 \mathrm{~h}$ tested for contextual fear memory $(n=8$ in each group). $* * p<0.01$, **** $p<0.00$ I vs age-matched WT littermates.

response were no significant difference in pre-training and four training trials among these groups (Supplementary Figure S2). In the present results, social isolation did not affect synaptic plasticity and fear conditioning in WT mice. We found that social isolation significantly impaired contextual fear conditioning in APP/PS1 mice, but not WT mice. These findings are consistent with previous report that isolated Tg2576 mice demonstrated significant impairment on contextual fear memory, but non-isolated Tg2576 mice and non-transgenic littermates showed no memory deficits (Dong et al, 2004). At 3 months of age, behavioral tests of fear conditioning showed that 3-month old APP/PS1 mice exhibited normal performance indicating that APP/PS1 mice were not born with any deficit in learning and memory. However, at this age APP/PS1 mice may develop cognitive impairment if rearing in isolation. We found that mice were separated into groups or socially isolated for 2, 4, 6, and 8 weeks. The impairment of contextual fear conditioning reached a significant level at 6 and 8 weeks after social isolation in APP/PS1 mice (data not shown). The 8-week social isolated mice exhibited impaired memory similar to that of 6-month-old APP/PS1 mice. Therefore, we used 8-week social isolation as a model to study social isolation-exacerbated AD development in APP/PS1 mice. In addition, social isolation increased hippocampal levels of $\mathrm{A} \beta_{40}$ and $\mathrm{A} \beta_{42}$, which was paralleled by increased $\beta$ - and $\gamma$-secretase activities whereas $\alpha$-secretase activity was unaltered. It is likely that social isolation led to oxidative stress (Schiavone et al, 2009), which in turn stimulated $\beta$ - and $\gamma$-secretase activity (Chan et al, 2009) resulting in increased $\mathrm{A} \beta$, which then triggered onset of cognition decline in the APP/PS1 mice. These results are consistent with previous reports showing that stress and glucocorticoids similarly promote APP processing along the amyloidogenic pathway (Catania et al, 2009) resulting in the exacerbation of $\mathrm{AD}$-like neuropathology (Billings et al, 2005; Green et al, 2006; Jeong et al, 2006; Srivareerat et al, 2009).

It was noted that 3-month-old APP/PS1 mice housed in group exhibited normal hippocampal LTP and contextual fear memory despite having higher levels of $\mathrm{A} \beta_{40}$ and $\mathrm{A} \beta_{42}$ than those of WT mice. It is possible that the increased levels of $\mathrm{A} \beta_{40}$ and $\mathrm{A} \beta_{42}$ seen in 3 months old group APP/PS1 mice did not reach threshold to have an impact on LTP and the memory until further exacerbation by social isolation.

\section{Linking $\mathrm{A} \beta$ to $\mathrm{p} 35$ and Memory Impairment}

In this study, we have demonstrated that social isolation increased calpain activity and $\mathrm{p} 25 / \mathrm{p} 35$ ratio, in parallel with the decreased membrane-associated p35 and surface expression of GluR1. These effects could be mediated by $\mathrm{A} \beta$ because $\mathrm{A} \beta$ has been shown to induce conversion of $\mathrm{p} 35$ to p25 (Lee et al, 2000). A $\beta$-induced synaptic dysfunction has been attributed to removal of the synaptic AMPA receptors. However, data linking p35 to synaptic removal of AMPARs is lacking. GluR1 phosphorylation at Ser831 by CaMKII is required for LTP (Barria et al, 1997; Mammen et al, 1997). Using a yeast two-hybrid screen, it has been demonstrated that p35 interacted with $\alpha$-CaMKII, which may contribute to synaptic plasticity and learning and memory (Dhavan et al, 2002). Here, we showed that GluR1 
phosphorylation at Ser831 and p35-GluR1-CaMKII complex component was significantly reduced in the isolated APP/ PS1 mice. We hypothesized that social isolation increased $\beta$ - and $\gamma$-secretase activities, $\mathrm{A} \beta$ level, and calpain activity leading to conversion of $\mathrm{p} 35$ to 25 . Decrease in membraneassociated p35 reduces $\alpha$-CaMKII synaptic distribution resulting in the synaptic removal of AMPARs. This hypothesis receives support from recent observations that A $\beta$-induced synaptic expression of AMPARs by reducing $\alpha$-CaMKII synaptic distribution (Gu et al, 2009) and $\mathrm{A} \beta$ infusion in combination with intruder psychological stress impaired spatial memory by reducing phosphorylated level of $\alpha$-CaMKII (Srivareerat et al, 2009).

It is important to identify and ameliorate social isolationinduced cognitive impairment. Previous study reported the effects of isolation rearing on spatial learning, hippocampal neurogenesis, and LTP could be reversed by subsequent group rearing ( $\mathrm{Lu}$ et al, 2003). The reversal effects on social isolation by subsequent group rearing will be investigated in the future study.

In summary, these results provide information concerning the cellular mechanisms of $\mathrm{A} \beta$ accumulation and increased severity of $\mathrm{AD}$-associated cognitive decline underlying adulthood social isolation. In addition, the findings that decreasing p35 degradation or blocking conversion of p35 to p25 rescued social isolation-induced decline of memory, which may provide a therapeutic approach for the retardation of $\mathrm{AD}$.

\section{ACKNOWLEDGEMENTS}

This study was supported by Grants NSC98-2321-B-006-009 from the National Science Council, NHRI-EX97-9716NI from the National Health Research Institute and Landmark Project (R026) of the National Cheng-Kung University of Taiwan.

\section{DISCLOSURE}

The authors declare no conflict of interest.

\section{REFERENCES}

Barria A, Muller D, Derkach V, Griffith LC, Soderling TR (1997). Regulatory phosphorylation of AMPA-type glutamate receptors by CaMKII during long-term potentiation. Science 276: 20422045.

Billings LM, Oddo S, Green KN, McGaugh JL, Laferla FM (2005). Intraneuronal Abeta causes the onset of early Alzheimer's disease-related cognitive deficits in transgenic mice. Neuron 45: 675-688.

Catania C, Sotiropoulos I, Silva R, Onofri C, Breen KC, Sousa N et al (2009). The amyloidogenic potential and behavioral correlates of stress. Mol Psychiatry 14: 95-105.

Chan A, Tchantchou F, Rogers EJ, Shea TB (2009). Dietary deficiency increases presenilin expression, gamma-secretase activity, and Abeta levels: potentiation by ApoE genotype and alleviation by S-adenosyl methionine. J Neurochemistry 110: 831-836.

Cruz JC, Tseng H, Goldman JA, Shih H, Tsai LH (2003). Aberrant Cdk5 activation by p25 triggers pathological events leading to neurodegeneration and neurofibrillary tangles. Neuron 40: 471-483.
Davis M (2006). Neural systems involved in fear and anxiety measured with fear-potentiated startle. Am Psychol 61: 741-756.

Dewachter I, Filipkowski RK, Priller C, Ris L, Neyton J, Croes S et al (2009). Deregulation of NMDA-receptor function and down-stream signaling in APP[V717I] transgenic mice. Neurobiol Aging 30: 241-256.

Dhavan R, Greer PL, Morabito MA, Orlando LR, Tsai LH (2002). The cyclin-dependent kinase 5 activators p35 and p39 interact with the $\alpha$-subunit of $\mathrm{Ca}_{2} /$ calmodulin-dependent protein kinase II and a-actinin-1 in a calcium-dependent manner. J Neurosci 22: 7879-7891.

Dong H, Goico B, Martin M, Csernansky CA, Bertchume A, Csernansky JG (2004). Modulation for hippocampal cell proliferation, memory, and amyloid plaque deposition in APPsw (Tg 2567) mutant mice by isolation stress. Neuroscience 127: 601-609.

Farris W, Mansourian S, Chang Y, Lindsley L, Eckman EA, Frosch MP et al (2003). Insulin-degrading enzyme regulates the levels of insulin, amyloid beta-protein, and the beta-amyloid precursor protein intracellular domain in vivo. Proc Natl Acad Sci USA 100: $4162-4167$.

Fischer A, Sananbenesi F, Pang PT, Lu B, Tsai LH (2005). Opposing roles of transient and prolonged expression of p25 in synaptic plasticity and hippocampus-dependent memory. Neuron 48: 825-838.

Green KN, Billings LM, Roozendaal B, McGaugh JL, LaFerla FM (2006). Glucocorticoids increase amyloid-beta and tau pathology in a mouse model of Alzheimer's disease. J Neurosci 26: 9047-9056.

Gu Z, Liu W, Yan Z (2009). \{beta\}-Amyloid impairs AMPA receptor trafficking and function by reducing Ca2+/calmodulindependent protein kinase II synaptic distribution. J Biol Chem 284: 10639-10649.

Haass C, Schlossmacher MG, Hung AY, Vigo-Pelfrey C, Mellon A, Ostaszewski BL et al (1992). Amyloid beta-peptide is produced by cultured cells during normal metabolism. Nature 359: 322-325.

Hsiao YH, Chen PS, Lin CH, Gean PW (2008). N-acetylcysteine prevents $\beta$-amyloid toxicity by retarding proteolytic degradation of a cyclin-dependent kinase 5 activator in cultured cortical neurons. J Neurosci Res 86: 2685-2695.

Hsieh H, Boehm J, Sato C, Iwatsubo T, Tomita T, Sisodia S et al (2006). AMPAR removal underlies Abeta-induced synaptic depression and dendritic spine loss. Neuron 52: 831-843.

Iwata N, Tsubuki S, Takaki Y, Shirotani K, Lu B, Gerard NP et al (2001). Metabolic regulation of brain Abeta by neprilysin. Science 292: 1550-1552.

Jankowsky JL, Fadale DJ, Anderson J, Xu GM, Gonzales V, Jenkins NA et al (2004). Mutant presenilins specifically elevate the levels of the 42 residue beta-amyloid peptide in vivo: evidence for augmentation of a 42-specific gamma secretase. Hum Mol Genet 13: 159-170.

Jeong YH, Park CH, Yoo J, Shin KY, Ahn SM, Kim HS et al (2006). Chronic stress accelerates learning and memory impairments and increases amyloid deposition in APPV717I-CT100 transgenic mice, an Alzheimer's disease model. FASEB J 20: 729-731.

Johnson-Wood K, Lee M, Motter R, Hu K, Gordon G, Barbour R et al (1997). Amyloid precursor protein processing and $\mathrm{A} \beta_{42}$ deposition in a transgenic mouse model of Alzheimer disease. Proc Natl Acad Sci USA 94: 1550-1555.

Kang J, Lemaire HG, Unterbeck A, Salbaum JM, Masters CL, Grzeschik KH et al (1987). The precursor of Alzheimer's disease amyloid A4 protein resembles a cell-surface receptor. Nature 325: 733-736.

Kim JJ, Fanselow MS (1992). Modality-specific retrograde amnesia of fear. Science 256: 675-677.

Kitazawa M, Oddo S, Yamasaki TR, Green KN, LaFerla FM (2005). Lipopolysaccharide-induced inflammation exacerbates tau pathology by a cyclin-dependent kinase 5-mediated pathway 
in a transgenic model of Alzheimer's disease. J Neurosci 25: 8843-8853.

Knobloch M, Farinelli M, Konietzko U, Nitsch RM, Mansuy IM (2007). Abeta oligomer-mediated long-term potentiation impairment involves protein phosphatase 1-dependent mechanisms. J Neurosci 27: 7648-7653.

Knobloch M, Mansuy IM (2008). Dendritic spine loss and synaptic alterations in Alzheimer's disease. Mol Neurobiol 37: 73-82.

Koo EH, Squazzo SL (1994). Evidence that production and release of amyloid beta-protein involves the endocytic pathway. J Biol Chem 269: 17386-17389.

Kusakawa G, Saito T, Onuki R, Ishiguto K, Kishimoto T, Hisanaga S (2000). Calpain-dependent proteolytic cleavage of the p35 cyclin-dependent kinase 5 activator to p25. J Biol Chem 275: 17166-17172.

Lee MS, Kwon YT, Li M, Peng J, Friedlander RM, Tsai LH (2000). Neurotoxicity induces cleavage of p 35 to p 25 by calpain. Nature 405: 360-364.

Leissring MA, Farris W, Chang AY, Walsh DM, Wu X, Sun X et al (2003). Enhanced proteolysis of betaamyloid in APP transgenic mice prevents plaque formation, secondary pathology, and premature death. Neuron 40: 1087-1093.

Li S, Hong S, Shepardson NE, Walsh DM, Shankar GM, Selkoe D (2009). Soluble oligomers of amyloid $\beta$ protein facilitate hippocampal long-term depression by disrupting neuronal glutamate uptake. Neuron 62: 788-801.

Lu L, Bao G, Chen H, Xia P, Fan X, Zhang J et al (2003). Modification of hippocampal neurogenesis and neuroplasticity by social environments. Exp Neurol 183: 600-609.

Lue LF, Kuo YM, Roher AE, Brachova L, Shen Y, Sue L et al (1999). Soluble amyloid beta peptide concentration as a predictor of synaptic change in Alzheimer's disease. Am J Pathol 155: 853-862.

Mammen AL, Kameyama K, Roche WK, Huganir RL (1997). Phosphorylation of the $\alpha$-amino-3-hydroxy-5-methylisoxazole 4-propionic acid receptor GluR1 subunit by calcium/calmodulindependent kinase II. J Biol Chem 272: 32528-32533.

McLean CA, Cherny RA, Fraser FW, Fuller SJ, Smith MJ, Beyreuther $\mathrm{K}$ et al (1999). Soluble pool of Abeta amyloid as a determinant of severity of neurodegeneration in Alzheimer's disease. Ann Neurol 46: 860-866.

Nikolic M, Dudek H, Kwon YT, Ramos YF, Tsai LH (1996). The cdk5/p35 kinase is essential for neurite outgrowth during neuronal differentiation. Genes Dev 10: 816-825.

Noble W, Olm V, Takata K, Casey E, Mary O, Meyerson J et al (2003). Cdk5 is a key factor in tau aggregation and tangle formation in vivo. Neuron 38: 555-565.

Patrick GN, Zhou P, Kwon YT, Howley PM, Tsai LH (1998). p35, the neuronal-specific activator of cyclin-dependent kinase 5
(Cdk5) is degraded by the ubiquitin-proteasome pathway. J Biol Chem 273: 24057-24064.

Patrick GN, Zukerberg L, Nikolic M, de la Monte S, Dikkes P, Tsai LH (1999). Conversion of p35 to p25 deregulates Cdk5 activity and promotes neurodegeneration. Nature 402: 615-622.

Perez RG, Soriano S, Hayes JD, Ostaszewski B, Xia W, Selkoe DJ et al (1999). Mutagenesis identifies new signals for beta-amyloid precursor protein endocytosis, turnover, and the generation of secreted fragments, including Abeta42. J Biol Chem 274: 18851-18856.

Phillips RG, LeDoux JE (1992). Differential contribution of amygdala and hippocampus to cued and contextual fear conditioning. Behav Neurosci 106: 274-285.

Schiavone S, Sorce S, Dubois-Dauphin M, Jaquet V, Colaianna M, Zotti $\mathrm{M}$ et al (2009). Involvement of NOX2 in the development of behavioral and pathologic alterations in isolated rats. Biol Psychiatry 66: 384-392.

Shoji M, Golde TE, Ghiso J, Cheung TT, Estus S, Shaffer LM et al (1992). Production of the Alzheimer amyloid beta protein by normal proteolytic processing. Science 258: 126-129.

Snyder EM, Nong Y, Almeida CG, Paul S, Moran T, Choi EY et al (2005). Regulation of NMDA receptor trafficking by amyloidbeta. Nat Neurosci 8: 1051-1058.

Srivareerat M, Tran TT, Alzoubi KH, Alkadhi KA (2009). Chronic psychosocial stress exacerbates impairment of cognition and long-term potentiation in $\beta$-Amyloid rat model of Alzheimer's disease. Biol Psychiatry 65: 918-926.

Trinchese F, Liu S, Battaglia F, Walter S, Mathews PM, Arancio O (2004). Progressive age-related development of Alzheimer-like pathology in APP/PS1 mice. Ann Neurol 55: 801-814.

Tsai LH, Delalle I, Caviness Jr VS, Chae T, Harlow E (1994). p35 is a neural-specific regulatory subunit of cyclin-dependent kinase 5. Nature 371: 419-423.

Wilson RS, Krueger KR, Arnold SE, Schneider JA, Kelly JF, Barnes LL et al (2007). Loneliness and risk of Alzheimer disease. Arch Gen Psychiatry 64: 234-240.

Zhang Y, Kurup P, Xu J, Carty N, Fernandez SM, Nygaard HB et al (2010). Genetic reduction of striatal-enriched tyrosine phosphatase (STEP) reverses cognitive and cellular deficits in an Alzheimer's disease mouse model. Proc Natl Acad Sci USA 107: 19014-19019.

Zhao CT, Li K, Li JT, Zheng W, Liang XJ, Geng AQ et al (2009). PKCdelta regulates cortical radial migration by stabilizing the Cdk5 activator p35. Proc Natl Acad Sci USA 106: 21353-21358.

Zhao WQ, Santini F, Breese R, Ross D, Zhang XD, Stone DJ et al (2010). Inhibition of calcineurin-mediated endocytosis and $\alpha$-Amino-3-hydroxy-5-methyl-4-isoxazolepropionic acid (AMPA) receptors prevents amyloid $\beta$ oligomer-induced synaptic disruption. J Biol Chem 285: 7619-7632.

Supplementary Information accompanies the paper on the Neuropsychopharmacology website (http://www.nature.com/npp) 